\title{
シュウ酸浴によるアルミニウム陽極酸化皮膜の 電気伝導特性およびスイッチング現象
}

\author{
岡田元次， *定岡芳彦*，*酒井義郎
}

1 緒 言 (Introduction)

アルミニウムの陽極酸化皮膜は，均一な薄膜であり， 良好な絶縁特性から電解コンデンサーとして用いられて いる. 実用的見地から，電解質溶液中での電気 伝 導特 性，誘電損失および耐電圧について関心が払われてきた が，近年電子材料とくに IC (集積回路) の絶縁体や機 能蒵子としての态用を目的として，乾燥状態での研究が 多くなされている

今回はシュウ酸浴中からの陽極酸化皮膜について, 上 面に金属を真空蒸着し，電気伝導特性，絶縁破壊および スイッチング現象について測定したので報告する.

シュウ酸浴加らの酸化皮膜は，緻密なバリヤ一皮膜と 多孔質層から成る複合皮膜構造 ${ }^{3}$ をなしている。この複 合皮膜は電解条件によって内部構造が異なるため, 電気 伝導特性扝よび絶縁破壊現象は複雑であり，まだ十分に 解明されてはいない，絶縁破壞に到る機構としてイオン

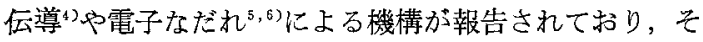
のときの耐圧も種々》㐫り，これらは試料作成条件に大 きく依存している.ここではとくに，化成時の電流密度 および最大印加電圧を小さく括さえ，できるだけ緻密な 皮膜を作ることに心がけた。

\section{2 実 験 (Experimental)}

高純度アルミニウムはく $\left(20 \times 50 \times 0.1 \mathrm{~mm}^{3}\right.$, 純度 99.99\%）を素地とし，アセトンで洗浄した後，10\% 水 酸化ナトリウム水溶液に 5 分間つけ, 脱脂して用いた. 過塩素酸 $(d=1.60)$ と無水酶酸の混合液 $(7: 1)$ によ り, 浴温度 $20^{\circ} \mathrm{C}, 30 \mathrm{~V}$ の印加電圧で電解研摩を行なっ た.ついで $3 \%$ シュウ酸浴を用い, 試料の両面にカソー ド配置し，電流密度 $4 \mathrm{~mA} / \mathrm{cm}^{2}$ でかくはんしながら 陽極酸化した。

酸化皮膜の厚みは化成時間を変えることで調節し， 0.5 4.5 $\mu \mathrm{m}$ とした. 蒸留水で水洗した後, 乾燥器内で 乾燥させた．さらに真空中 $200^{\circ} \mathrm{C}$ で 3 時間加熱して揮発 性残留分を取り除いた。つで, 皮膜上に電極 ( $\mathrm{Au}, \mathrm{Ag}$, Al) を直径 $2 \mathrm{~mm}$ の円形に真空蒸着して試料電極とし

* 當媛大学工学部工業化学科（松山市文京町 3) Key words : Electrical Conductivity, Switching, Aluminum Oxide, Oxide Films, Anodization te.

皮膜の厚みは万能ブリッジ（横河製作所 BV-Z-13 B 型）により電気容量を測定し， $\hat{\varepsilon}=8.8$ として計算した. 電気伝尊度は, 直流電圧を印加し，エレクトロメータ （タケダ理研製 TR-8651 型）により電流を測定して求 めた。測定は真空中で行ない， $200^{\circ} \mathrm{C}$ で 3 時間熱処理し たのち所定の温度で測定した。

\section{3 結果と考察 (Results and Discussion)}

アルミニウム陽極酸化皮膜の電流一電圧特性を Fig. 1 に示す. 低電圧領域では，電流注電圧に比例しオーム則 が成立しているが，電圧が高くなると電流の急増がみら れ，これ以上では電圧の 2 3 乘に比例して電流が変化 し，非オーミックな領域となる。また，図中のオーミッ

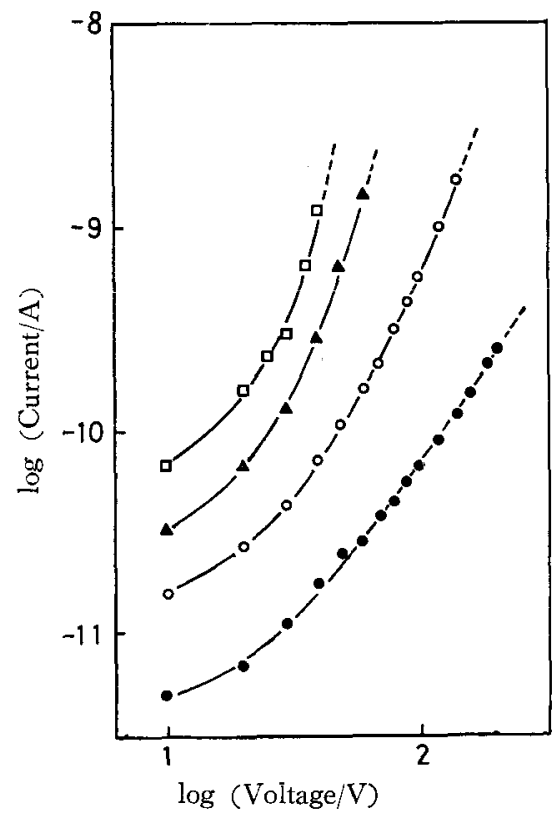

Fig. 1 Current-voltage characteristics of $\mathrm{Al} / \mathrm{Al}_{2} \mathrm{O}_{3} / \mathrm{Au}$ sandwich cell, as a function of film thickness, in vacuum after heat treatment

Temperature $393 \mathrm{~K}$

Film thickness: $\square 0.5 \mu \mathrm{m}, \boldsymbol{\Delta} 1.0 \mu \mathrm{m}$ $\bigcirc 1.6 \mu \mathrm{m}, \boldsymbol{\ominus} 4.5 \mu \mathrm{m}$ 
クな領域における電流の膜厚依存性から，ここで用いた 複合皮膜中の電気伝導梳，皮膜の大部分を占める多孔層 の部分でおきていると考えられる・多孔層の下部にある バリヤー皮膜は，この化成条件（ソウ電圧の最大值 30 V) では, 各膜厚の試料について $0.3 \mu \mathrm{m}$ 以下 $^{7,8)}$ とみ られるが，このバリヤー皮膜の部分を通して流れる電流 の寄与は少ないといえる。

\section{1 電極效果}

低い電圧城で，バイアス極性を変えたときの電圧一電 流特性江両方向に対してほぼ同じ值を示し, 各膜厚 (1,

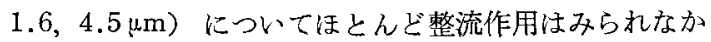
った.一方，印加電圧の極性によって電流值を異にする 整流作用を示す例も報告9,10) されており，その原因とし ては，皮膜の表面付近と素地金属の界面付近で化成時に 金属原子と酸素原子の量論比が異なることによるとされ ている. 本実験でも熱处理をしない場合には整流作用が 少しみられたが，真空中で熱処理すると，この整流作用

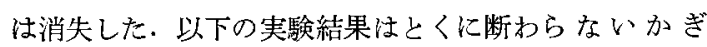
り，熱処理後の測定值である.また，素地のアルミニウ 厶を正極にした方が電流值が安定しており，種々の測定 条件に抒いて再現性がよかったので，このバイアス方向 を採用し，順バイアス（素地アルミニウムを正極，上部 蒸着金属急急極）と呼ぶことにする。

伝導度の温度依存性から求めた伝導の活性化エネルギ 一をFig. 2 に示す. 活性化エネルギー $E_{\mathrm{a}}$ は $\mathrm{Au}, \mathrm{Ag}$, $\mathrm{Al}$ と浪ほ同し值を示し，電極金属汇よる差はほとん どみられない，また，それぞれの金属の仕事関数の違、 から予想11されるような電流值の差異もなく，電極効果 がほとんどみられない。これらのことから，電気伝導に 対する電極界面からの寄与は非常に少ないといえる・し たがって，アルミニウム陽極酸化皮膜はバルク支配型の 電気伝導を示すと考えられる。

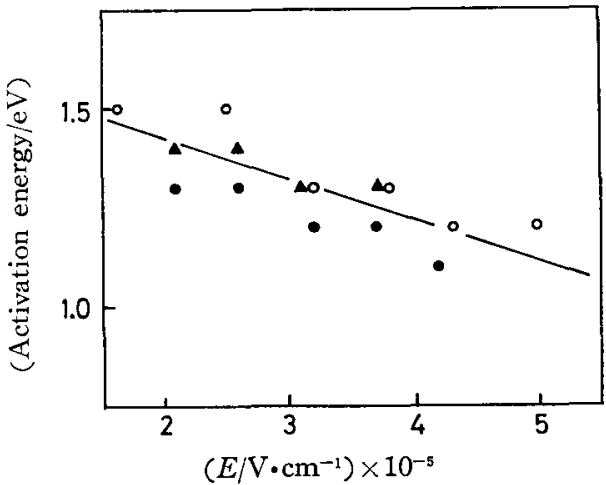

Fig. 2 The activation energy obtained from temperature dependence of conductivity

Metal : $\mathrm{OAu}, \boldsymbol{A g}, \mathrm{Al}$ on $\mathrm{Al} / \mathrm{Al}_{2} \mathrm{O}_{3} /$ Metal structure

\subsection{Poole-Frenkel 効果}

絶縁体に電場を印加したとき，トラップ準位加らの実 効電位障壁が低下することに伴う放出電流の増加柱, Poole-Frenkel 効果 ${ }^{123}$ とよばれ, 電圧一電流特性は次式 徉5.

$$
\begin{aligned}
& I \propto \exp \left[\left(\beta_{\mathrm{PF}} E^{1 / 2}-\phi_{0}\right) / k T\right] \\
& \beta_{\mathrm{PF}}=\left(\mathrm{e}^{3} / \pi \varepsilon_{0} \varepsilon\right)^{1 / 2} \\
& こ こ て ゙ \quad \phi_{0}: \text { 障壁高さ } \quad E: \text { 電場 } \\
& \quad \beta_{\mathrm{PF}}: \text { Poole-Frenkel 定数 }
\end{aligned}
$$

$E^{1 / 2}$ に刘して Schottky plot を Fig. 3 亿示す. 各膜 厚について直線関倸が成立してお方りこの傾きから求め た $\beta_{\mathrm{PF}}$ を Table 1 亿示す. 下端は $\varepsilon=8.8$ として求め

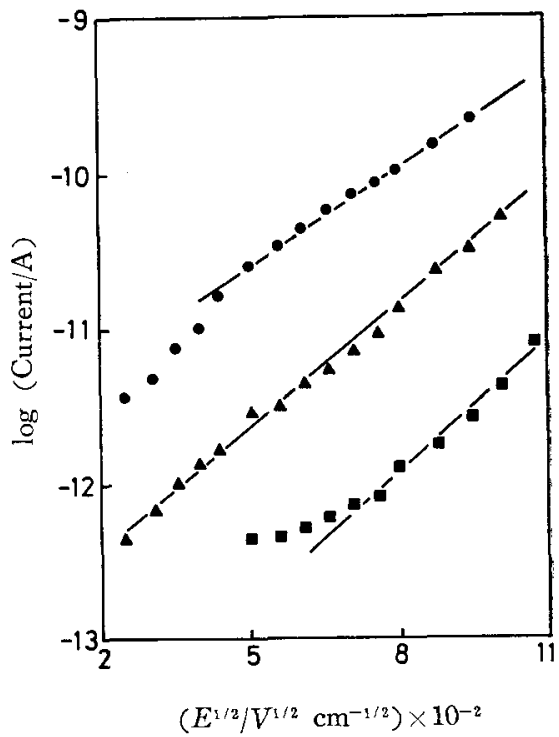

Fig. 3 Schottky plot of measured currentvoltage curve on $\mathrm{Al} / \mathrm{Al}_{2} \mathrm{O}_{3} / \mathrm{Au}$ structure

Temperature : $323 \mathrm{~K}, \boldsymbol{\Delta} 373 \mathrm{~K}, 393 \mathrm{~K}$

た理論值で，いずれもこれに近い值となっている。ま た， $\beta_{\mathrm{PF}}$ が一定の值を持っと仮定すれば，（1）式より $\log I \propto d^{-1 / 2}$ なる関係が成立することになるこのグラ フからほぼ直線関倸が確かめられ，この直線の傾きから 求めた $\beta_{P F}$ は $3.0 \times 10^{-4}$ 程度であり, 上記の Table 1 の值にかなり近い值を示した.この值は, Schottky 効 果による定数 $\left.{ }^{22} （ \beta_{\mathrm{S}}=1 / 2 \quad \beta_{\mathrm{PF}}\right)$ とは明確に区別でき， Poole-Frenkel 型の伝導を示すと考えられる.また，こ のことは前に述べたように電極依存性がないことと合致 する. Fig. 2 の活性化エネルギーの電圧依存性から $\phi_{0}$ $=1.5 \mathrm{eV}$ が得られた.これらのことから, 非オーミッ クな領域に㧍ける電気伝導は, Poole-Frenkel 効果によ ると考えられる。

\section{3 高電場印加による絶縁破壊}


Table 1 Thickness dependence of Poole-Frenkel const. $\beta_{\mathrm{pF}}$ $\varepsilon=8.8, \quad T=393 \mathrm{~K}$

\begin{tabular}{c|c|c}
\hline $\begin{array}{c}\text { Counter } \\
\text { electrode }\end{array}$ & $\begin{array}{c}\text { Thickness } \\
(\mu \mathrm{m})\end{array}$ & $\begin{array}{c}\text { Poole-Frenkel const. } \\
\beta_{\mathrm{pF}}\end{array}$ \\
\hline $\mathrm{Au}$ & 0.5 & $3.4 \times 10^{-4}$ \\
& 0.7 & $4.5 \times 10^{-4}$ \\
& 1.0 & $3.4 \times 10^{-4}$ \\
& 1.6 & $2.1 \times 10^{-4}$ \\
& 2.7 & $2.3 \times 10^{-4}$ \\
& 4.5 & $2.4 \times 10^{-4}$ \\
\hline $\mathrm{Al}$ & 1.9 & $2.3 \times 10^{-4}$ \\
\hline $\mathrm{Ag}$ & 1.9 & $3.9 \times 10^{-4}$ \\
\hline
\end{tabular}

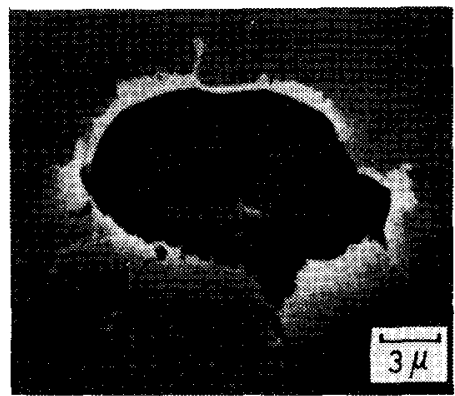

Fig. 4 Scanning electron micrograph of a oxide film with gold counter electrode after the breakdown have occurred

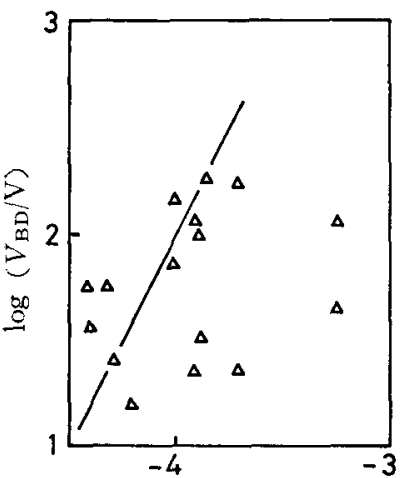

(a)

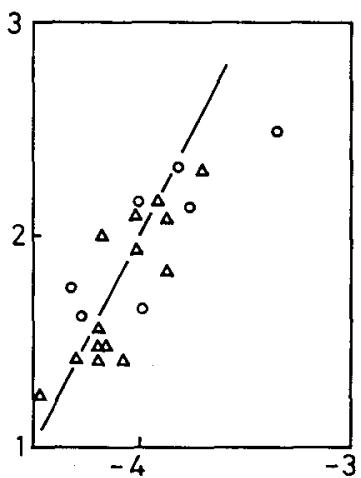

(b)
酸化皮膜汇高電場を印加すると電流の急増現象がみら れ，さらに電場を大きくすると絶縁破壞をおこす，その 際クレーター状の破壊跡がみられる (Fig. 4).このと きの電圧を破壊電圧 $V_{\mathrm{BD}}$ とよぶことにする，室温にお ける $V_{\mathrm{BD}}$ を各膜厚に対してプロットしたものを Fig. 5 に示す. 空気中（a）では， $V_{\text {BD }}$ は全体的に低く，非常 に大きなばらつきを示すが，真空中での值 (b) からさ らに $120^{\circ} \mathrm{C}$ で 3 時間熱处理すると，(c) のよ5にかな り安定した $V_{\mathrm{BD}}$ 特性を示した. とくに膜厚が大きい試 料で法熱処理の効果が顕著である。

この熱処理を施したものでも，空気中に長時閒放置子 ると $V_{\mathrm{BD}}$ が小さくなりふふたたび熱処理前の Fig. 5 (a) の状態にもどる．また，乾燥空気中ではこの変化が非常 に少ないことから，空気中に含まれる水分が破壊電圧に 大きく影響を及ぼし，本来の酸化皮膜の持つ絶縁破壊電 圧 ${ }^{6,13)}$ を低下させていると思われる。 また，Fig. 5 (b)， (c) で上部電極の種類を変えても $V_{\mathrm{BD}}$ 浪ほぼ同じ值を 示した，さらに各金属上極性を変えて同様の測定を行 なっても，ほとんど差異はみられなかった，真空中熱処 理後の $V_{\mathrm{BD}}$ は膜厚の 2 乗に比例する傾向にある.

つぎに，破壊電圧に及ぼす温度の效果について Fig. 6 に示す，破壊現象が単に発熱に上るもの上すれば，温度 増加によって $V_{\mathrm{BD}}$ の低下が予測されるが，20〜120足 の範囲では $V_{\mathrm{BD}}$ の変化はみられなかった。

絶縁破壞がおきた後の状態は，ショートする場合と子 たたびもとの高抵抗一と瞬時に回復する場合とがある。 前者はパルス $(100 \mathrm{~V}, 0.005 \mu \mathrm{F}$ による放電）を加える と, 高抵抗状態に回復した。これは, 絶縁破壊時に局部 的なフィラメント状の低抵抗部分が形成されて㧍り，パ ルスの印加によって，この部分に電流功集中し破壊され

$\log$ (Thickness/cm)

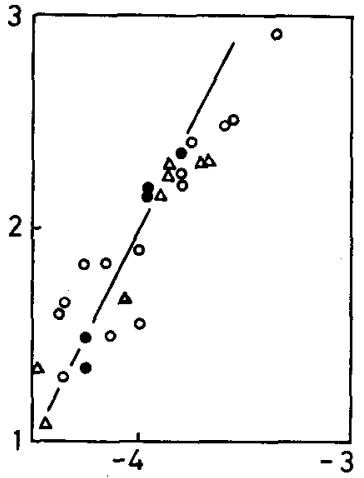

(c)

Fig. 5 Thickness dependence of breakdown strength at the various conditions. Solid lines are slope 2

Counter electrode: $\mathrm{Al}, \triangle \mathrm{Ag}, \bigcirc \mathrm{Au}$

(a) in air at ambient temperature (b) in vacuum at $323 \mathrm{~K}$

(c) in vacuum at $323 \mathrm{k}$ after heat-treatment 


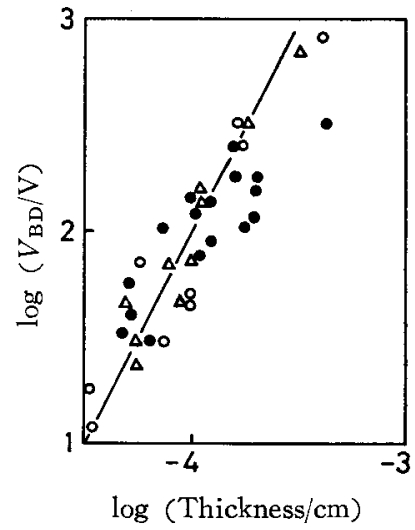

Fig. 6 Temperature dependence of breakdown voltage as a function of film thickness

Temperature: $293 \mathrm{~K}, \bigcirc 323 \mathrm{~K}, \triangle 393 \mathrm{~K}$

てフィラメントが消失したことによる. また, 自己回復 性がある場合は，瞬時の発熱で上部電極がはく離したこ とによる、絶縁破壊をおこした後も，上記の手段で回復 させて測定を繰り返した場合の $V_{\mathrm{BD}}$ Fig. 7 に示 す. 回数を追うごとに $V_{\mathrm{BD}}$ が大きくなっている.これ は, 試料の薄、部分あるいは久陷部から先に破壊されて いくことによる.したがって，V $V_{\mathrm{BD}}$ のばらつきは皮膜 の不均一性汇基づくものと考光られる.なお，Fig. 5,6 の值は 1 2 回目の $V_{\mathrm{BD}}$ を採用したものである.

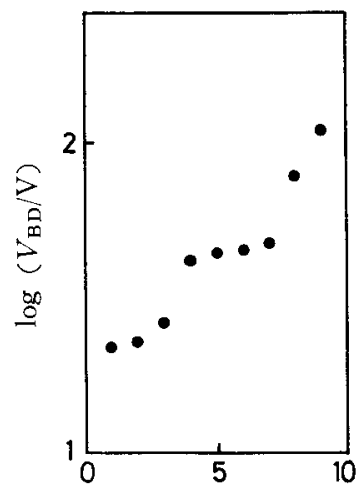

Number of run

Fig. 7 Breakdown voltages succesively measured on $\mathrm{Al} / \mathrm{Al}_{2} \mathrm{O}_{3} / \mathrm{Au}$ structure Film thickness : $0.73 \mu \mathrm{m}$

\section{4 スイッチング現象}

これまで述べたように高電場印加時に絶縁破壊が生じ るが，高抵抗 $(51 \mathrm{M} \Omega)$ を直列に入れて試料電圧を印 加した場合，完全な絶縁破壞まで到らず，クレーターの 発生がないままに, Fig. 8 に示すような低い抵抗状態 に移行するのが観測された。 その際, 低電圧でのオーム

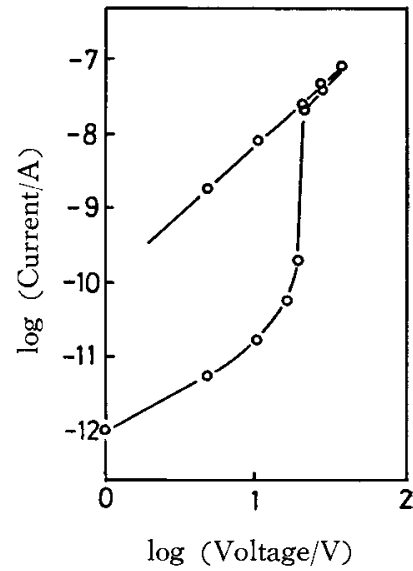

Fig. 8 Current-voltage characteristics in switching on $\mathrm{Al} / \mathrm{Al}_{2} \mathrm{O}_{3} / \mathrm{Au}$ structure at $353 \mathrm{~K}$

Load resistance: $51 \mathrm{M} \Omega$

Film thickness: $0.53 \mu \mathrm{m}$

則領域加ら 2〜4 乗則域となり，つ、には電流の急上昇 がおこり低抵抗状態へと移行した（以下，スイッチング とよぶ).ささらに電圧を加えた場合, 電流電圧の 2 乗 に比例して変化した. 一度低抵抗状態になると, 電圧を 取り去っても低抵抗状態が保たれ，、わゆるメモリー効 果を示す. この状態は長時間放置するとふたたび高抵抗 状態一回復するのがみられる(Fig. 9).

このよらな長時間にわたる緩やかな回復は，試料中に 蓄積した電荷の放電過程に基づくと考えられる。このと き, 低電圧では回復が速く, 電圧が高くなるにしたがっ

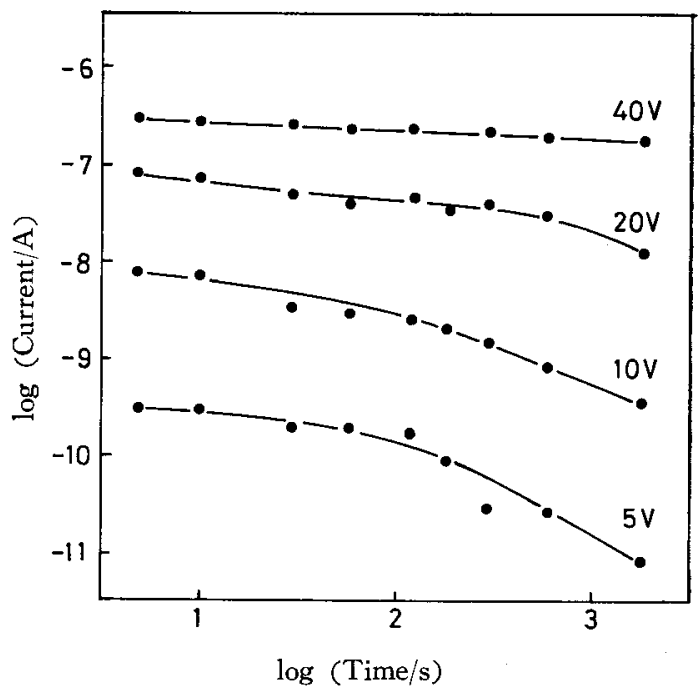

Fig. 9. Variation of recovery time to the high impedance state with applied voltage after switching 
て回復が遅くなっている。

以上のことから，このタレーターの発生を伴わないス イッチング現象は，空間電荷制限電流 (SCLC) による と考えられ，電流の急上昇はトラップが完全に満たされ ることによっておこり，前項で述べた破壊電圧は，この 電流急上昇状態に相当する電圧と考えられる.この両者 は同一の機構により発生し，クレータ一あるい性回復性 の有無によってのみ区別されると考えられる。また， $V_{\mathrm{BD}}$ の值において極性効果および電極効果がないこと と符合する. Fig. 9 で回復特性が電圧によって異なる のは，トラップ準位が広く分布していることによると思 われる.トラップの分布が指数関数的なものであるとす れば，電圧一電流特性注次式によって与方

$$
\begin{aligned}
& I \propto V^{l+1} / d^{2 l+1} \\
& E_{\mathrm{f}}=k T_{\mathrm{c}} \ln \left[\frac{(l+1)^{2} \mathrm{e} H_{0}}{l(2 l+1) \varepsilon \varepsilon_{0}} \cdot \frac{d^{2}}{V} \cdot\right. \\
& \left.\left(\frac{x}{d}\right)^{1 /(l+1)}\right]
\end{aligned}
$$

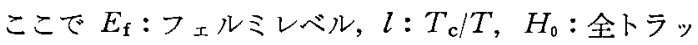
プ密度, $d$ : 膜厚, $T_{\mathrm{c}}$ : 特性温度, $\varepsilon$ : 比誘電率である

(3) 式に拉ける distribution parameter $l$ は高電場 での電圧-電流特性から $l \simeq 2$ が得られた.さらに電流膜厚特性 (Fig. 10) 加らも，ほほ2 に近い值が得られ た. また， $E_{\mathrm{f}} \simeq E_{\mathrm{a}}$ として温度特性から求めたものは $l$ $=2.5$ であり, 同㥞の傾向を示し, トラップ密度 $H_{0}$ は $10^{22} / \mathrm{cm}^{3}$ 程度となった。

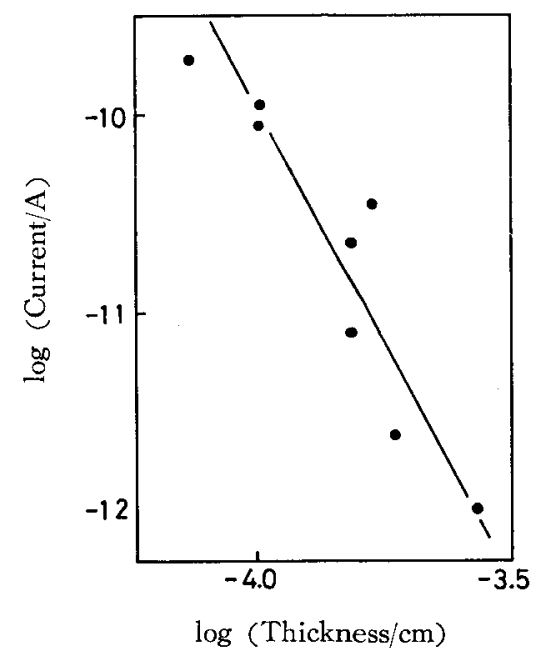

Fig. $10 \log I$ vs. $\log d$ plot for eq. (3) at $E>2.5 \times 10^{5} \mathrm{Vcm}^{-1}, 393 \mathrm{~K}$

このスイッチング現象は, 印加電生の極性を変えても 同様にあらわれ，低抵抗状態になった後に逆バイアスに しても同しく低抵抗状㦔に保たれた. また，これらの現 象は上部電極の金属の種類を変えても同様にあらわれ， バルク支配型のスイッチングであると結論される.

\section{4 結 論 (Conclusion)}

シュウ酸浴加らの陽極酸化皮膜の電気伝導特性は，サ ンドイッチ型構造の試料に㧍いて熱処理を施したもの は, 上部電極の種類や印加電圧における極性効果がな $く$, Poole-Frenkel 型の電気伝導を示した. 高電場印加 時においては，クレーターの発生を伴ら絶縁 破壊の他 に，非破壊的なスイッチング現象が観測された.このス イッチングは，空間電荷制限電流 (SCLC) に支配され た伝導状態から、トラップが満たされたことによる低抵 抗状態への移行と考えられる。 $<1829>$ (Received Feb. 1, 1979)

$$
\text { 文 献 }
$$

1) 鴨志田元孝, 電気化学 44, 491 (1976).

2) J.J. Randall, Jr., E.N. Urfer, H.F. Puppolo and W.S. Goruk, J. Electrochem. Soc. 117, 1218 (1970).

3) H. Takahashi, M. Nagayama, H. Akahori and A. Kitahara, J. Electron Microscopy 22, 149 (1973).

4) A.H.M. Shousha, J. Non-Cryst. Solids 17, 100 (1975).

5) F. Forlani and N. Mnnaja, J. Vac. Sci. Technol. 6, 518 (1969).

6) A.H.M. Shousha, D.L. Pulfrey and L. Young, $J$. Appl. Phys. 43, 15 (1972).

7) H.J. de Wit, Ch. Wijenberg and C. Crevecoeur, $J$. Eelectrochem. Soc. 123, 1479 (1976).

8）永山政一，高橋英明，下化 5, 850 (1972).

9) 任藤教男, 门化学総論」No. 7, 213 (1975), 東京大学出版会.

10) N.N. Axelrod and N. Schwartz, $J$, Electrochem. Soc. 116, 460 (1969).

11) P.L. Young, J. Appl. Phys. 46, 2794 (1975).

12) J.G. Simmons, Phys. Rev. 155, 657 (1967).

13) C.T. Morse and G. J. Hill, Proc. Brit. Cearm. Soc. 23 (1970).

14) P. Mark and W. Helfrich, J. Appl. Phys. 33, 205 (1962).

\section{is is \\ Electrical Conductivity and Switching \\ Phenomena of the Anodic Oxide Films on Aluminum from Oxalic Acid}

Genji OKada, Yoshihiko Sadaoka and Yoshiro SAKAI (Department of Industrial Chemistry, Faculty of Engineering, Ehime University, Matsuyama, Ehime)

The DC conductivity, breakdown strength and switching mechanism of the oxide films formed by the steady-state anodization of aluminum in oxalic acid was studied.

In $I-V$ characteristics, the oxide films heat-treated in a vacuum revealed non-rectification and no electrode effect for the various evaporated metals. The conduction was bulk limited and was of the Poole-Frenkel type at intermediate voltages. At high voltages the breakdown normally associated with the crater formation took place, but non-destructive switching was obtained in circuits having a high resistance in series. It was concluded that the on-state was caused by space-charge-limited current, assisted by the trap becoming filled. 